\title{
SOCIAL CRITICISM MEANING OF PUTRA NUSANTARA SONG LYRICS SHAGGY DOG FEAT IWA K.
}

(Critical Discourse Analysis Teun A.Van Djik)

\author{
Aa Qonaatun \\ Universitas Banten Jaya \\ aaqonaatun@unbaja.ac.id
}

\begin{abstract}
Music is one of the communication media to convey implied messages. Music is also a cultural means that is present in society as a construction of social reality as outlined in the form of song lyrics. The most prominent social music functions are found in the lyrics. An ideal song lyrics do not only contain ideas to entertain but also have moral or idealistic messages and have the power of constructive social criticism. One of the musicians who dared to create songs about social problems was the band Shaggydog who released a song titled Putra Nusantara. The purpose of this study was to determine the meaning of social criticism on the song Putra Nusantara using the Teun A. Van Djik approach covering the dimensions of the text, dimensions of social cognition and dimensions of social context. The text dimension will analyze the macro structure, superstructure and micro structure, then discuss it into the dimensions of social cognition and social context dimensions to find the meaning of criticism of the song. After analyzing the micro structure, which is based on syntactic, semantic, stylistic and rhetorical structures, it turns out that there are many clauses that are incoherent with one another or based on the superstructure, in the temple scheme many meanings are even lost. However, based on the overall meaning, the song implies to state officials who do not pay attention to proper education for children. However, based on social cognition, the song cannot be proven true if the school is expensive. Macro structure can be seen from the relationship of the text with what is in the minds of listeners. Then, in the social context, there are a lot of satirical expressions that can be known meaning based on the social context.
\end{abstract}

Keywords; $A W K$, social criticism, song lyrics, putra nusantara

\section{INTRODUCTION}

Humans are social beings who cannot live alone but need other beings to be able to complement each other. Besides that humans also need to communicate so that the needs they need can be conveyed well. Someone who is able to communicate well tends to be considered more successful in his life than someone whose communication skills are lacking. Signs conveyed can be verbal and non-verbal which are interpreted as communication with signs, words or languages.

Music is one of the communication media to convey implied messages. Music is also a cultural means that is present in society as a construction of social reality as outlined in the form of song lyrics. Music can be used as a person's daily needs, as expressed by philosopher Nietszche (Rez, 2008: 15) that life without music is a mistake, because almost every day we always intersect with what is called music. Whether we realize it or not, music is considered able to unite the community, both the upper, middle and lower classes. According to (Sulastianto, 2007: 131) music and sociology have the same relation to society, and have the same thing that is interacting with the social environment. Therefore musicians when making a work are more or less influenced by various political, economic, and social conditions.

The most prominent social music functions are found in the lyrics. Lyrics are part 
of music which is a means to convey messages. Song lyrics can be used as a means of describing important social reality, meaning that it is beneficial for humans to perceive existence and its relationship in the reality of social life. An ideal song lyrics do not only contain ideas to entertain but also have moral or idealistic messages and have the power of constructive social criticism.

One of the musicians who dared to create songs about social problems was an indie band from Yogyakarta, namely Shaggydog who released a song titled Putra Nusantara. Song Putra Nusantara itself is one of the songs in the album Putra Nusantara which was released by Shaggydog on the 71st independence day of the Republic of Indonesia, namely in 2016. In the song, the lyrics tell about how the state of education took place in Indonesia. The lyrics of the song Putra Nusantara show that there are still many children who do not have the right to education because of the high cost of schooling today. Song Putra Nusantara itself is a social critique first song written by Shaggydog. The song tells how life and development in a magnificent city, but there are still forgotten. The forgotten thing is Indonesian children who were victims of legislative candidates during the election campaign. Indonesian children who later could not enjoy education properly. In fact, education is one of the most important things to prepare competitive human resources in achieving success in the era of globalization. Education is the main pillar for the progress of a nation (Liriwati in Indragiri Journal, 2018: 3).

This inspired writer to examine deeper the meaning of Shaggydog song lyrics which indicated contain resistance charges. In the lyrics, Shaggydog is seen as brave and decisive in conveying social criticism. Writer wants to find out whether in song lyrics Putra Nusantara describe resistance as perceived by the audience in the lyrics of the song.

In this study, writer wanted to know the meaning of social criticism in the Shaggydog song lyrics entitled Putra Nusantara by analyzing the message in the form of a text discourse (song lyrics), using Teun A. Van Dijk's discourse analysis by dissecting the dimensions of text, social cognition and social context.

\section{METHODOLOGY}

\section{Approach}

The approach used in this study is interpretive qualitative research in which writer makes a thorough observation of the signs in the lyrics of the song Putra Nusantra Shaggydog. The analytical approach used in this study uses a discourse analysis, which is a broad set of methodological principles, applied to the forms of utterance and text, both naturally occurring and previously planned. Discourse analysis places language or discourse not merely a tool for producing and sending meaning/message. Language or discourse is a strategy used by people with the aim of creating certain effects (Daymon and Holloway, 2008; 219 in 2010).

\section{Focus of Research}

The focus of this study is the meaning of social criticism in the song lyrics of Putra Nusantara by Shaggydog. While the subfocus of this research is the meaning of social criticism in song lyrics Putra Nusantara seen from the dimensions of text, social cognition and social context.

For the analysis model used is the Van Djik analysis model in which this analysis model analyzes discourse that focuses on text structures such as macro structure, super structure, and micro structure in the lyrics of the song. Van Dijk's theory through his work creates a framework 
for discourse analysis that can be used. He sees a discourse consisting of various structures / levels, each of which supports each other. Van Dijk divides it into three levels:

1. Macro structure, this is the global/general meaning of a text that can be understood by looking at the topic of a text. The theme of this discourse is not only the content, but also the particular side of an event.

2. Super Structure is the framework of a text, how the structure and discourse elements are arranged in the text as a whole.

3. Microstructure is the meaning of discourse that can be observed by analyzing words, sentences, propositions, clauses, paraphrases used and so on.

\section{Sources and types of data}

The sources of data in this study are:

\section{Primary}

Data obtained directly from the object of the study is by analyzing the object of study, namely song lyrics Putra Nusantara.

The following is song lyrics Putra Nusantara sung by Shaggydog and Iwa K which are the primary data sources of this study.

mataku memandang dari jendela

kaca

saat aku berada dalam angkutan

kota

anak-anak kecil bermain di jalanan

menjulurkan tangannya untuk

meminta-minta

penuh harapan oh penuh tantangan

penuh harapan ooh yeah penuh

tantangan badan hitam legam terbakar

matahari

sehitam warna langit kota yang

penuh polusi

seharusnya mereka berada di

sekolah

tapi sekolah mahal bagi mereka

yang tak punya

o o o ow kota megah dan indah tapi di balik itu semua ada cerita o o o ow pembangunan melaju ada yang terlupa, coba lihat ke jalan

woo hooo yoo kota yang indah, kota nan megah

woo hooo tapi ada satu yang terlupa di sana

woo hooo pembangunan terus melaju woo hooo yeah kini coba lihat ke jalan

kami juga mengingatkan anda janji bapak-bapak dan ibu-ibu waktu pemilu jangan hanya berbusa-busa, jangan sampai itu semua hanya jadi mimpi semu, omong kosong belaka

untuk putra-putri indonesia berdoa belajar berusaha yoo iwa $k$ come on

[rap]

di antara belantara ... di tengah kota dimana berada keresahan dan air mata

di s-n-lah meratap dengan terbata-

bata

saudara kecilku bermain dan

meminta-minta

bersiram janji-janji surga dewata 
hanya tak lebih dari sekedar main kata

karena sekolah pun tetap mahal butuh biaya

bagi masa depan bangsa putra nusantara

o o o ow kota megah dan indah tapi di balik itu semua ada cerita o o o ow pembangunan melaju ada yang terlupa, coba lihat ke jalan

kami putra nusantara ingin pintar bersahaja

jangan kau pandang kami dengan sebelah mata

kami putra nusantara ingin pintar bersahaja nasib negeri di tangan kami, ingat itu, ingatlah selalu ingatlah selalu, ingatlah selalu, ingatlah selalu

(kami putra nusantara ingin pintar bersahaja jangan kau pandang kami dengan sebelah mata kami putra nusantara ingin pintar bersahaja nasib negeri di tangan kami, ingat itu, ingatlah selalu)

\section{Secondary Data}

Writer takes secondary data sources from various sources as references, such as biographies songwriters and album descriptions from official websites, opinions and theories by experts from articles, journals, book and e-book. The author undertakes secondary sources to strengthen the results of the analysis of the main sources.

\section{Data Collection Techniques}

Collection techniques used in this study are as follows:

1. Documentation; The writer downloaded the song lyric file Putra Nusantara sung by Shaggydog from the website KapanLagi.com

2. Literature Study; researchers read and study a number of books, articles, and journals related to research to support research.

\section{Data Analysis Techniques}

Data collection in the analysis of song research Putra Nusantara is by analyzing song lyrics or it can also be called discourse analysis. The critical discourse analysis that the writer has tried to describe briefly above, the writer will use the approach proposed by Teun A. Van Dijk. The analysis used in this study uses a discourse analysis approach, namely a broad set of methodological principles, applied to utterance and text, both naturally and previously planned. Discourse analysis places language or discourse not merely a tool for producing and sending meaning/message. Language or discourse is a strategy used by people with the aim of creating certain effects (Daymon and Holloway, 2008; 219).

\section{RESULTS AND DISCUSSION}

Based on the limitation of the problem, there are three things that can be discussed in songs Putra Nusantara, namely the dimensions of the text, the dimensions of social cognition and also the dimensions of social connection.

1. The Meaning of Song Putra Nusantara based on the Text Dimension.

Discussion of song Putra Nusantara 
which is discussed based on the text dimension means also analyzing the song's form based on the micro structure or structure of the song itself. So, what is discussed is the form of text without involving outside elements.

In the first analysis carried out in the first and second rows of the song is one complete sentence. In the traditional syntax of the Indonesian language, the two lines have a form of the Subject-PredicatePattern. And the statement also has a proposition which is an information clause of the statement in a sentence, namely in the clause. "saat aku berada di dalam angkutan kota" Meanwhile, the main clause in that sentence is "mataku memandang dari jendela kaca". Semantically or meaningfully there is how the word " $k u$ " refers to the first person. This means referring to people who are in the text. So, it can be interpreted that people who are singing the song are people who are looking at an object from a city transportation which is also conceptually not clear what the city transportation is. In semantics, the concept is a mental picture of a word (Saif et al, 2017).

Then, in the third and fourth rows, there is a sentence when coherently coupled, lines one and two have coherence and can also be concluded if the object lost in the first and second rows is children in the third and fourth rows. There are also two clauses in the third and fourth lines. "Anak-anak kecil bermain di jalanan" are the main clauses. "Anak anak kecil" is a subject in that clause. The fourth line is a child clause or clause. And there is also a reduction that should be the conjunctive "sambil." From the two clauses, it can be concluded that there are meaningfully several children playing on the streets and also reaching out to begging or begging.

So that, in a sense it can be concluded that the first line to the fourth is one verse. Also, there is a coherence between the first and second sentences. So, it can also be concluded that there is one event in one of these stanzas.

Whereas in the fifth and sixth rows are canals or additions to the first stanza. Stylistically, there is an emphasis on the first stanza, especially in the fourth and fifth rows. The phrase "penuh harapan" and "penuh tantangan" is a description of the third and fourth lines in the first stanza or second sentence, and the phrases are repeated in the sixth row. It can also be concluded that these phrases are the condition of these small children who are very hopeful of the people around them. "tantangan" is also meaningful to the conditions on the road. This form is also a form of rhetoric where there is an emphasis on the meaning of the child who is still playing but also earning a living for his life.

Stylistically, singer Shaggy dog has stylistics to repeat words for reinforcement of meaning and also for improvisation, the singer makes a pause by repeating the word "oo" repeatedly.

In the next line or seventh row is an illustration of the condition of the small children. "Badan hitam legam" is the subject of a sentence. And there is a "referensi" to the phrase. Reference is a reference or direction on a particular object (Saif et al, 2014). The object here is small children in the previous sentences. The word "terbakar" is a figurative meaning of being exposed to the sun. It wants to show the power of meaning in small children, most of whose lives are outside the home so that the sun is too hot. "matahari" itself has a concept as a noun that emits a hot beam so that it will feel hotter when it is in the daytime.

When connected to the next line, which is in the line "sehitam warna langit 
kota yang penuh polusi" does not have coherence because the color of the sky during the day is not black, "yang penuh polusi" has a reference as well as the concept of disposal of vehicles or factories in the form of black smoke.

In the stanza, it should have a fairly strong coherence. However, in the stanza has two different focus. In half the stanza is more directed to the condition of the children who are begging which is more directed to the first and second stanzas. However, in this verse there are two different focuses where half are not related to the previous one. The singer immediately leads to the school. The ninth and tenth lines are also a complete sentence. There are even three clauses in the sentence. The first clause is "seharusnya mereka berada di sekolah" which also functions as the main clause. The word "seharusnya" is a word that refers to a situation that is not true. And in the next line is the clause in the main clause. However, the clause is the opposite of the condition of the main clause which also has a conjunction "tapi." This situation describes where the age is or the age of the children, these children should be educating when the singer sees them. However, they do not go to school on expensive grounds. And there is a clause in a clause "mereka yang tak punya."

Then, there is a refraint which consists of two verses where the two stanzas are very similar. The phrase "kota megah dan indah" is actually a clause with a reduction "adalah." And is related to the second clause "tapi di balik itu semua ada cerita". The second clause has the opposite meaning to the affirmation of "tapi." However, the opposite meaning is not seen because it should be the opposite of the word "megah" to "kecil" and "indah" to be "buruk." However, the singer prefers to use clauses "di balik itu semua ada cerita". And, not told stories like what. Then, there is also a clause that looks "pembangunan melaju" more at ongoing development. And there is a command sentence in the clause "coba lihat ke jalan." The command sentence will usually be directed to the second person, that is the listener of the song. And there is no definite focus because the road is a medium for transportation that has many activities there. However, in coherence, this refers to the initial stanzas, namely children's activities on the road.

In the second verse there are similar sentences. The difference is in repeating the word "ada yang terlupa" and "coba lihat ke jalan" It can be concluded also if the sentences are a rhetoric to strengthen the meaning that the listener must see the difference or contrast of development and also the grandeur and beauty of a city.

In the next stanza after referrals, there is a pronoun "kami" which attempts to use a formal pronoun, "anda." The pronoun "anda" is a formal form for the second person. Formal forms are usually used for office activities. And, more explained in the clause "janji bapak- bapak dan ibu- ibu waktu pemilu." It is also still not clearly addressed to whom. Today, there are two types of elections, namely legislative elections and executive. Legislative elections refer to members of the DPRD or DPR. Meanwhile, executive elections refer to regional or state leaders. The word "berbusa-busa" refers to a mouth that ejects foam or is more emphasized in the connotation meaning to "suara yang berapiapi" Then, in the clause "jangan sampai itu semua hanya jadi mimpi semu, omong kosong belaka" refers to giving false hope .

There are also invitations to children of Indonesia as a whole "untuk putra putri Indonesia: berdoa, belajar, berusaha" This 
form is an invitation sentence because there are no subjects there, which means it is also a form of invitation for the second plural, namely Indonesian children.

Then, Iwa K, an Indonesian rap singer sang with a rap tone, as follows:

di antara belantara ... di tengah kota

dimana berada keresahan dan air

mata

di s-n-lah meratap dengan terbatabata

saudara kecilku bermain dan

meminta-minta

bersiram janji-janji surga dewata

hanya tak lebih dari sekedar main

kata

karena sekolah pun tetap mahal butuh biaya

bagi masa depan bangsa putra

nusantara

Rap is a form of music where the singer tries to speak quickly but there are still rhymes at the end of the sound. Can be seen the game or also the selection of words is very important (McCoy, 2017). On the Iwa K song, all lines will end with the letters a / and even more neatly arranged with the ta / ta / ta / ta / ra pattern. This is the stylistic form of the Iwa $\mathrm{K}$ singer who is always looking for the right rhyme. In the first row of the temple, Iwa K likens the city to the wilderness which is conceptually very far apart. Cities are very different from villages where people prefer to work together and help each other. The city is considered a wilderness because its life is like a forest where animals prefer to prey on each other. Strengthened by the words "keresahan" and also "air mata" Anxious states are also reinforced in the next lyrics, namely "meratap dan terbata bata" Then, the next lyrics refer to the initial stanza or more references to the little ones.

In the last verse before referencing there is a verse that contains the desires of Indonesian children. In "kami putra nusantara ingin pintar bersahaja" is an explanatory clause about the desire of Indonesian children to be more advanced and smart. And there is no clarity of the word "kau" in the next verse.

As a conclusion, the meaning in the dimensions of text can be seen from the semantic form which will also see concepts from existing nouns. In addition, social criticism based on the text leads more to the indifference of state officials.

2. Explaining the meaning of social criticism in song lyrics Putra Nusantara seen from social cognition.

After analyzing the meaning of social criticism based on text, now writer will discuss based on social cognition. Social cognition itself refers more to social perceptions of something so that it will have an effect on mental social (Flavel, 2016). In fact, social cognition itself will have a kind of suggestion for people who have social cognition. Stories will also have an impact on social cognition, for example ghost stories that will cause someone to be very scared (Mar, 2017). As an example of social cognition, Indonesian society is predominantly Muslim. As Muslims, pigs are forbidden animals. So, if you see cooked pork, it will cause nausea that is not necessarily felt by other people who are not Muslims.

The first social cognition is found at the beginning of the song as follows: mataku memandang dari jendela kaca saat aku berada dalam angkutan kota anak-anak kecil bermain di jalanan 
menjulurkan tangannya untuk meminta-minta

In the stanza that the singer was in city transportation see little kids who should be playing on the street and begging. The social cognition in the temple is how sad the experience of attorney is Shaggydog's because in its cognizance, little children should not be on a very dangerous road. However, these small children even play on the streets unlike other children who are supposed to play in the field or around the house. Also, verb begging should be directed at adults. In the temple, a very different thing is seen where the small children are actually begging.

The emphasis on the pain of the suffering of these children can also be seen in how the children's skin is not clean, but black. Social cognition is that the perception of a child should be clean and not jet black like street children. This can be seen in the verse:

\section{matahari}

badan hitam legam terbakar penuh polusi

sehitam warna langit kota yang sekolah seharusnya mereka berada di tapi sekolah mahal bagi mereka yang tak punya

And then, the bodies of these children are equated with a city full of pollution. In many people's cognition, pollution can actually make breathing short. However, here the depiction of the city is frenzied with pollution activities carried out by adults. This is in stark contrast to the situation of small children who even wandered in the city.
Social cognition is also found in the Iwa K. Rapp which says the city as a wilderness. In the cognition of many people, the wilderness is a gathering place for animals so that there is a deep fear of the wilderness. Here, it is shown if the city is the same as the wilderness. In community cognition, the city is a gathering place for many people who work from the haram and halal. In fact, there are many struggles of minors in the city. So, the saying "the strong is the one who survives" is true.

However, in terms of social cognition, the above statement is not appropriate because the government has even freed up children's education to junior high school level. If it is said that education is expensive it is not in accordance with those in the field (Reviews of National Policy and Education, 2015).

3. The Meaning of Social Criticism on the Song Lyrics of Putra Nusantara seen from the Social Context

In the science of communication, context is very important to see meaning. Context itself is a situation or condition that can affect the meaning of a word or even utterance (Kamanga, 2017). For example, the word bapak which means lexically means that a man's parents will change their meaning in a social context. In the social context, the word "bapak" means someone who is respected. The social context is also related to social cognition; how does the community mean something (Gianeli, 2013).

In the social context, small children are things that must be protected and must not be separated from the role of parents. In this song, the little ones can even play on the road. This means that these small children have acted like adults who have to live on the road. This can be seen in the first stanza of the song. 
Then, in referrals "ada cerita" are things that can be guessed based on the social context. There is a story here is the journey of how the street children tried to make money for their lives. And also the black picture of urban pollution is a challenge that street children have to overcome because they are outside.

"Bapak-bapak dan ibu-ibu waktu pemilu jangan hanya berbusa-busa" if interpreted in a social context, the fathers and mothers who win the election as legislators who try to voice the people and also as executives who carry out the policy should see more votes when the campaign was up to "berbusa-busa" which meant how long they expressed promises during the election but were not implemented.

\section{CONCLUSION}

From the analysis based on the text which is the micro structure of discourse analysis that sees a meaning of text based on the text itself. In the text based on micro structures discussed based on syntactic, semantic, stylistic and rhetorical structures. After discussing this, it turns out that many clauses are incoherent with one another or based on the superstructure. In the stanza scheme many meanings are even lost. However, based on the overall meaning, the song implies to state officials who do not pay attention to proper education for children. However, based on social cognition, the song cannot be proven true if the school is expensive. The macro structure can be seen here or see the relationship of the text to what is in the minds of listeners. Then, in the social context, there are a lot of satirical expressions that can be known meaning based on the social context.

\section{REFERENCES}

Anonymous. 2015. Reviews of National Policies for Education, Education in Indonesia. Reviews of National Policies for Education; Indonesia.

Austin McCoy. 2017. Rap music. Cultural History, University of Michigan DOI:

$$
10.1093 \text { / acrefore / }
$$$$
\text { 9780199329175,013,287 }
$$

Flavell, J.H. 1979. Metacognition and cognitive monitoring: A New area of cognitive-developmental inquiry. American Psychologist, 34(10), 906-911.

Gianelli C., Scorolli C., Borghi A. M. (2013). Acting in perspective: the role of body and of language as social tools. Psychol. Res. 77 40-52

Hidayat. 2010. Menyusun Skripsi dan Tesis.

Bandung: Informatika.

Idhar Rez. 2008. Music Record Indie Label; Cara Membuat Album Independen, Bandung; PT Mizan Bunaya Kreative.

Liriwati, Fahrina Yustiasari. 2018. Keberadaan Masyarakat Ekonomi ASEAN (MEA) dalam Mendorong Sinergitas Kontribusi Pendidikan Tinggi Keagamaan Islam (PTKIS) Menuju Generasi Indonesia Emas 2045. Indragiri Jurnal, Volume 1 Nomor 4. Halaman 3. The Official Publication of PT. Indragiri Dot Com Indonesia.

Saif, H., Fernandez, M., He, Y., Alani, H. 2014. On Stopwords, Filtering and Data Sparsity for Sentiment Analysis of Twitter. In: Proc. 9th Language Resources and Evaluation Conference (LREC), Reykjavik, Iceland.

Sulastianto, Harry. 2007. Seni Budaya. Grafindo Media Pratama. 